\title{
Different Pathophysiology of Gastritis in East and West? A Western Perspective
}

\author{
Hans-Peter Wirth Manqiao Yang \\ GastroZentrumKreuzlingen, Kreuzlingen, Switzerland
}

\author{
Key Words \\ Helicobacter pylori - Chronic atrophic gastritis · Pathogenic \\ factors
}

\begin{abstract}
Background: Gastritis results from multifactorial gastric mucosal injury. Helicobacter pylori $(\mathrm{Hp})$ is the main cause, and associated diseases have typical underlying patterns of gastritis. Gastric ulcer and gastric cancer (GC) develop from chronic atrophic corpus gastritis (CAG) which therefore represents the most important pattern. GC incidences in East Asia are substantially higher than elsewhere, and this should be also reflected by higher prevalences of CAG and characteristic differences in pathophysiology compared to the West. Summary: The few available comparative studies of gastritis in Eastern and Western patients are summarized. The main pathogenic factors of gastritis are discussed together with their limitations to explain local differences in disease outcome. Emphasis was put to also include less wellestablished pathogenic host and environmental factors of possible impact. Conclusions: CAG is more prevalent in East Asian areas with high GC incidences than the West. Geographic heterogeneity of associated diseases is due to differences in $\mathrm{Hp}$ prevalence and virulence as well as modulating host and environmental factors. The following may contribute to the higher burden of CAG in the East: $A B D$ type of CagA with vacA s1 and babA2 alleles of $H p$, host Lewis(b) expression in sej/sej nonsecretors, $H$. heilmannii, low parietal cell mass, high sodium and nitrate intake, preferences in
\end{abstract}

vegetable and fruit consumption, cigarette smoking, air pollution, alcohol. Conversely, green tea, nonfermented soy products and rice may confer protective effects. $H p$ is on the decline, but also in a world cleared from this bacterium, differences in host genetics will continue to modify gastric disease outcome together with maintained customs as part of cultural diversity.

(c) 2016 S. Karger AG, Basel

\section{Definitions and Introduction}

Gastritis denotes (cellular) inflammation due to gastric mucosal injury. Gastropathy referring to gastritis with minimum inflammation was originally described for bile reflux but is similar for other external causes like nonsteroidal anti-inflammatory drugs (NSAIDs), alcohol, chemicals and radiation.

Autoimmune gastritis is corpus-limited and spares the antrum. In contrast, Helicobacter pylori $(H p)$ gastritis is antrum-predominant and superficial in the majority, but can spread to the corpus and gradually destroy the gastric glands. Within years to decades, a minority of Western patients undergo a progressive course with atrophy and intestinal metaplasia of the gastric antrum and/or corpus as precancerous condition for noncardia gastric cancer

For an Asian perspective on gastritis, see Suzuki and Mori [Inflamm Intest Dis DOI: 10.1159/000446301].

\section{KARGER}

E-Mail karger@karger.com

www.karger.com/iid
(C) 2016 S. Karger AG, Basel

2296-9403/16/0013-0113\$39.50/0
PD Dr. med. Hans-Peter Wirth

GastroZentrumKreuzlingen

Bahnhofstrasse $33 \mathrm{~b}$

$\mathrm{CH}-8280$ Kreuzlingen (Switzerland)

E-Mail hp.wirth@hin.ch 
(GC) $[1,2]$. In both forms, the risks grow exponentially with increasing grade and extent of atrophic gastritis and intestinal metaplasia [3-5], which are assessed by histology $[6,7]$. The development of atrophy is accelerated after vagotomy [8] and possibly under long-term acid suppression [9].

\section{Classification and Etiologies}

Despite recent enthusiasm [10-12], gastritis remains a rather neglected area. This is reflected by the actual ICD10 classification still lacking $H p$ gastritis. Revision is underway. The tendency points to an etiology-based list of multiple causes. Although outdated, the original ABC classification $[13,14]$ remains popular, supposedly because of comprehensiveness despite simplicity: A refers to autoimmune, $\mathrm{B}$ to bacterial (infectious) and $\mathrm{C}$ to chemi$\mathrm{cal}$, covering the most relevant causes. The Kyoto proposal [10] is built around these main groups. Besides $\mathrm{Hp}$ and $H$. heilmannii, other infections nonspecific to the stomach can cause gastritis. Similarly, noninfectious systemic diseases can affect the stomach like Crohn's disease, sarcoidosis, vasculitis, allergies, eosinophilia and celiac disease. Gastropathies were mentioned before. A remaining group of unknown etiologies decreases as knowledge increases.

\section{Comparisons of Eastern with Western Gastritis}

Representative population-based surveys of the EastWest difference (EWD) of gastritis are virtually unavailable. Two comparisons of Japanese versus Canadian or Dutch patients showed more severe and extensive chronic atrophic corpus gastritis (CAG) in Japanese patients based on endoscopy or serum pepsinogens $[15,16]$. Chinese versus Dutch patients had more antral atrophy and intestinal metaplasia that occurred at younger age [17]. Intestinal metaplasia in the antrum and corpus of duodenal ulcer (DU) patients was more often among Koreans than Americans, Colombians or South Africans despite equal density of $H p$ and degree of active gastritis [18]. In Japanese versus Swedish DU patients, histologies were essentially identical. Gastric ulcer (GU) patients had more atrophy and intestinal metaplasia in the antrum and corpus than DU patients [19]. In $\mathrm{Hp}$-positive nonulcer patients, neutrophilic folliculitis, intestinal metaplasia and atrophy in the antrum but not corpus were more frequent in Koreans and Japanese than Americans [20]. Comparing gastritis of different age cohorts of UK and Japanese nonulcer dyspepsia patients, corpus predominant gastritis or pangastritis in Japanese patients was more common, and atrophy and intestinal metaplasia more extensive and severe [21]. Differences for corpus atrophy were greatest in the middle and older age groups. $H p$ positivity was equally high: 78 versus $71 \%$ in UK versus Japanese patients or 90 versus $88 \%$ including serology, indicating low $H p$ or its loss in some.

\section{Conventional Pathogenic Factors and Limitations}

Autoimmune (metaplastic atrophic) gastritis is inherited and female predominant, and occurs mainly in northern Europe [22]. In the East, the disease is too rare to explain higher prevalences of CAG and GC. Moreover, GC affects more males than females.

The role of NSAIDs, including aspirin, and the interactions with $\mathrm{Hp}$ are complex. NSAIDs can induce inflammation, peptic ulcers and possibly mucosal atrophy. But NSAID ulcers can occur in virtually normal mucosa, most long-term users do not develop significant gastritis, and with respect to GC, NSAIDs are protective $[23,24]$. Consumption, once maybe higher in the West, is increasing worldwide due to demographics. NSAIDs do not seem to contribute to the EWD of CAG, but CAG influences the risk for NSAID-induced gastroduodenal lesions [25].

Despite the multifactorial pathogenesis of CAG and $\mathrm{GC}, H p$ is the main and primary cause. Geographic heterogeneity in $\mathrm{Hp}$-associated diseases is generally explained by different prevalences of $H p$. The mere prevalence, however, is of limited importance because associated diseases correlate poorly. Surprisingly, in epidemiological studies, odds ratios (ORs) for GC in $\mathrm{Hp}$ positive Japanese patients were not higher than in Western subjects except for one study [26]. In fact, ORs in 2 of 5 compiled studies from Japan did not $[27,28]$ and in one [29] only marginally reached significance. In one study, increased GC risk correlated significantly with CAG but not $H p$ positivity [28]. Accordingly, in four prefectures of Japan with different GC mortality ratios, the risks correlated with the local prevalences of CAG but not of $H p$ [30]. The findings suggest that CAG is strongly related to GC development in Japan, but $H p$ infection is not [26, 31]. Also, with advancing atrophy and intestinal metaplasia, colonization density of $H p$ decreases and presumably so does the pathogenic impact $[5,32]$.

Pathogenicity and carcinogenicity of $H p$ is highly variable. Polymorphisms of bacterial virulence factors like cag pathogenicity island, $v a c A$ and genes for outer mem- 
brane proteins and motility [33], as well as of host genes related to inflammatory response (IL-1B, IL-1RN, IL-10, $T N F \alpha$ ) are important but cannot fully explain different regional, ethnic, gender-dependent and individual disease outcomes [34-38]. Complications occur in only a fraction of infected subjects, whereas the majority remains unaffected despite harboring the same microbes. GC and ulcers occur with all types of $H p$ independent of virulence markers and also without $H p$.

Most East Asian strains contain the cag pathogenicity island, the vacA s1 allele and produce CagA of distinctive EPIYA motifs. All have been related to higher pathogenicity [39] and particularly the East Asian ABD types of CagA compared with lower pathogenic Western ABC types [40]. The number and types of CagA EPIYA motifs in addition to $v a c A$ alleles can better explain geographic and ethnic differences of $\mathrm{Hp}$-associated diseases in most but not all regions [41]. In Colombia, GC incidences are high despite Hp of Western-type CagA [42], and Mongolians are infected with $\mathrm{Hp}$ of non-East Asian-type CagA [43]. In Southeast Asia, the magnitudes of differences in GC incidences are incompletely reflected by the prevalences of the CagA EPIYA motifs and vacA genotypes, and the differences of genotypes were small or null between patients with gastritis, ulcer disease and GC [41].

Reports about the associations of genetic polymorphisms of $I L-1 B$ and $I L-1 R N$, and GC, CAG and ulcers are conflicting. Subsequent studies after the first descriptions found mostly null results [44-46]. A cumulative metaanalysis tended toward null overall associations but with a significant heterogeneity, and an analysis of Western versus East Asian studies revealed no difference [47].

Epidemiological studies show striking geographic and ethnic differences, migration effects and time trends in CAG, GC and peptic ulcers [5, 26, 35, 38, 48-50]. These started when $H p$ was still unknown and happened too fast to be explained by bacterial or host genetic changes $[35,38]$. The studies suggest that $H p$ prevalences started to decline in several regions parallel to economic development $[4,5,26,49]$. It was hypothesized that environmental factors not only had contributed to the pathogenesis of CAG but also to reduced acquisition of $H p$ [5]. The increasing $H p$ prevalences with age despite acquisition in childhood and rarely thereafter represent a cohort phenomenon [5]. This reflects high acquisition rates in the past and decreasing infection in subsequent generations [49]. The decline of $\mathrm{Hp}$ prevalences in the last 3 decades has been accelerated by antibiotic treatment.

\section{Concepts and Assumptions}

These notions support pathogenic factors in addition to autoimmunity, $H p$ and NSAIDs. Fundamentally changing living conditions in the last two centuries (in the West before the East) and that the dramatic drop of GC incidence worldwide started before the $\mathrm{Hp}$ era underscore the importance of the environment $[5,26,32,35$, $36,51,52]$. Supporting evidence is historic, and studies under today's living conditions tend to overestimate the effects of $H p$.

The merit goes to D.Y. Graham [35] who years ago proposed a pathogenic model of how the main etiologies of $H p$-associated diseases interplay and in which the environment more than (host and microbial) genetics determines the disease outcome. Crucial in this model is gastric acid secretion/corpus atrophy and its contributing factors.

Atrophy and its proximal spreading in $H p$ gastritis have been classified decades ago by Kimura and Takemoto $[53,54]$. The progression of $H p$ gastritis to CAG and GC (intestinal more than diffuse type) is multifactorial, involving a cascade of events where $\mathrm{Hp}$ infection in early childhood probably represents the initial key trigger [5, 35]. It was speculated that in the past, favored by malnutrition, low vitamin $\mathrm{C}$ and iron, frequent childhood infections, poor living conditions and other factors, episodes of hypochlorhydria occurred. These enabled $\mathrm{Hp}$ to repeatedly get access to the gastric corpus, cause inflammation, rapid destruction of glands and corpus atrophy already in young adulthood [35].

Information about CAG is partially hidden because studies dealt with ulcers or GC, or atrophy was indirectly assessed (pepsinogen). Using GC as an indicator lesion for CAG helps to spot the relevant literature. Similarly, the GU/DU ratio is useful because of different underlying patterns of gastritis and GC prevalences [55], although somewhat less reliable due to undeclared location and synchronic and metachronic DU and GU. Because GC is more prevalent in East Asia (China, Japan, Korea, Mongolia) than the West [56] and CAG is a precursor, the incidences of GC and CAG are related [57-59]. Due to a long co-pathogenesis, most risk factors probably contribute to both conditions underscoring the relevance of CAG.

An exact geographical definition of East and West was considered less important than the opportunities offered by natural experiments of various environments. 


\section{Pathogenic Factors of Gastritis beyond 'ABC'}

Additional host and environmental factors of possible relevance for the pathogenesis of gastritis in the East and West are discussed below.

\section{Other Infectious Pathogens}

Epstein-Barr virus infection and reactivation have been related to peptic ulcer disease [60] and GC. The virus is highly prevalent (around 90\%) in a special type of GC with lymphoid stroma (gastric lymphoepithelioma) [61]. Oral pathogens in periodontal disease were incriminated to carry a higher risk of gastric precancerous lesions [62].

A group of non- $H p$ helicobacters ( $H$. heilmanni sensu lato) of zoonotic potential can cause gastritis, ulcers, MALT-lymphoma and GC. Although rare compared with $H p$, their prevalence can reach $6 \%$ in Asia versus $<1 \%$ in the West [63]. Mixed infection with $H p$ can occur. Changing microbiota outcompeting $H p$ in hypoacidity may drive carcinogenesis after CAG has been established [64]. These pathogens might have a marginal effect on the EWD of CAG.

\section{Host Parietal Cell Mass}

Acid secretion co-determines disease outcome in $\mathrm{HP}$ gastritis because it defines how far the bacterium can spread and cause inflammation $[35,65]$. The more gastric glands, the longer they can resist critical destruction and hypochlorhydria [21,35]. As long as a minimum acid output is maintained, DU can occur. Gastric acid secretion is higher in DU patients than normal controls, and DU is inversely related to GC risk [55]. Conversely, GU indicates underlying CAG with reduced acidity, and ulcers occur at the proximally spreading front of atrophy $[53,66]$.

Asians were suggested to possess smaller parietal cell masses than Westerners: Maximum acid output was higher in Scots than Chinese female and male healthy controls and DU patients, and the difference remained after correction for body weight, sex, age, blood groups and other factors [67]. In a previous work, parietal cell counts in addition to acid output of DU patients had been measured, which correlated perfectly with maximum acid output [68]. Compared with an earlier cohort of Scots [69], Chinese subjects had significantly lower parietal cell counts. Acid outputs per $10^{9}$ parietal cells were similar in both groups, suggesting fewer parietal cells rather than functional impairment caused the difference. Regrettably, no histological data were collected. Studying DU patients born in the 1930s and southern Chinese from Hong Kong suggests that most patients in both groups had antrum- predominant gastritis due to $\mathrm{Hp}$ infection with low corpus atrophy. The fact that fasting and postprandial serum gastrin levels did not differ between the two groups supports the assumptions and indicates comparable functional antral G-cells. The data suggest that the effect of more pronounced CAG on acid secretion was small compared to a genetically lower parietal cell mass in Chinese patients. Reports about better responses of Asians versus Caucasians to proton pump inhibitors and histamine- 2 receptor antagonists were interpreted to indicate lower acid production/parietal cell mass among Asians [70]. Similarly, lower aspirin-induced gastroduodenal mucosal injury in Japanese versus Western patients was associated with lower gastric acid secretion [71].

\section{Histo-Blood Groups}

The $\mathrm{ABH}$-secretor and Lewis (Le) histo-blood group systems are associated with susceptibility to various infections and autoimmune diseases [72]. The rationale for $\mathrm{HP}$ is the secretion of antigens into saliva and gastric juice in secretors and gastric expression [73-75].

DU is more common with blood group 0 and nonsecretors [76]. Thus, non-0 blood groups and secretor status could predispose to CAG, GU and GC. This is concordant with data of blood group A being a risk factor for CAG/GU/GC in both Western and Eastern populations $[55,77,78]$, and was confirmed in a more recent study of Scandinavian blood donors [79].

Relative risks of $\mathrm{Le}(\mathrm{a}+)$ versus $\mathrm{Le}(\mathrm{a}-)$ patients of 1.8 for DU versus 0.7 for GU have been described [80]. This roughly corresponds to previous data [76]. Le antigens are oligosaccharides fucosylated by $\mathrm{Le}$ - and $\mathrm{Se}$-encoded fucosyltransferases. Individuals of the $\mathrm{Le}(\mathrm{a}+\mathrm{b}-)$ phenotype are mainly $\mathrm{Le} /-\mathrm{se} / \mathrm{se}$ nonsecretors. In $\mathrm{Le} /-\mathrm{Se} /-$ secretors, conversion to $\mathrm{Le}(\mathrm{b})$ is favored, yielding a $\mathrm{Le}(\mathrm{a}-\mathrm{b}+)$ phenotype with little or no Le(a) $[74,75]$.

$H p$ variably expresses human blood groups, mainly $\mathrm{Le}(\mathrm{x})$ and $\mathrm{Le}(\mathrm{y})$ but also A, B, H-1, Le(a), Le(b) and sialyl$\mathrm{Le}(\mathrm{x})$ [81]. Research focused rather on the bacterial counterparts of human gastric blood group antigens: $\mathrm{Hp} b a b A 2$ (blood group antigen-binding)-encoded adhesin, binding $\mathrm{Le}(\mathrm{b})$ and $\mathrm{H}-1$, and $s a b A$ (sialic acid-binding)-encoded adhesin [82, 83], binding sialyl-Le(x, a) antigens [84].

BabA is associated with an increased risk of DU and GC [85], but reports are inconsistent $[34,86]$. Effects may be confounded because BabA is more commonly expressed in $\mathrm{Hp}$ positive for the cag pathogenicity island and $v a c A$ s1 $[34,83]$. Interestingly, clinical outcome differed minimally between East Asian and Western strains using these markers [34]. In a recent meta-analysis, the 
only association observed of $b a b A 2$ positivity was with DU in Western but not Asian countries [87].

Asians differ from Caucasians in the point mutation $s e j$ with proposed partially retained secretor activity despite equal rates of nonsecretors $[88,89]$. The sej allele occurs with a frequency of $40 \%$ in Japanese and may enhance gastric attachment of $H p$ in Japanese nonsecretors [89].

SabA positivity of $H p$ was positively related to GC and CAG $[85,90]$ and negatively to DU. In contrast, in Taiwan, the SabA positivity rates of $H p$ were similar in DU, GU and gastritis and independent of whether atrophy was present or not [91]. SabA-positive strains seem to be less prevalent in Asia [92] and may not contribute to the EWD of CAG despite higher importance of SabA versus BabA in CAG/hypochlorhydria [91, 92].

The complex interactions of shared blood group antigens are still incompletely understood [93]. Blood group A is less prevalent in East Asia than Europe in contrast to CAG and GC. Increased host Le(b) expression combined with almost ubiquitous babA2+ Hp may contribute to higher pathogenicity in East Asia. In contrast, the $\mathrm{Le}(\mathrm{a}-\mathrm{b}-)$ phenotype with no functional Le gene is common among Africans [94] and may contribute to lower GC rates via low gastric Le(b) expression.

\section{Other Inherited Host Factors and Appendectomy}

Up to $3 \%$ of mainly diffuse type GC arise in inherited predisposition syndromes [58]. A higher prevalence of CAG was described among blue- versus brown-eyed nonulcer patients [95]. This may be related to autoimmune gastritis, which is more prevalent in northern Caucasians.

CYP2C19 polymorphisms with known EWD indirectly influence gastric pathology via metabolism of proton pump inhibitors, although a direct relationship was suggested [96].

Other genetic variants associated with an increased risk of GC and ulcer disease have been proposed: NOD1 and NOD2, IL-8, cyclooxygenase-2 gene [97, 98], sodium-dependent vitamin C transporter 2 (SLC23A2) [99, $100]$ and possibly others involved in inflammation and immunity [101]. The TLR-1 and FCGR2A loci were related to $H p$ seroprevalence [102].

An inverse association between blood cholesterol and CAG has been reported [32, 103]. In contrast, a high body mass index and hyperglycemia were related to a higher GC risk $[58,104]$. One study reported a lower appendectomy rate among GU versus DU patients and controls, suggesting an unremoved appendix increased the risk for CAG [76]. At the moment, there is insufficient evidence to assume that any of these factors have an impact on the EWD of CAG.

\section{Salt, Nitrate and Food Preservation}

High sodium consumption is associated with a higher risk of GC [48, 105-107] and GU but not DU [55]. Refrigeration instead of food preservation with salt and nitrate reduced salt consumption and has been linked to fewer premalignant lesions $[32,108]$. In Japan, the use of refrigerators increased from 9 to $91 \%$ between 1960 and 1970, and urinary sodium excretion decreased from 360 to 187 $\mathrm{mmol} / 24 \mathrm{~h}$ between 1955 and 1987 [109].

A survey of 24-hour urine sodium and nitrate excretions in 24 countries showed significant positive correlations with GC mortality in men and women [109]. East Asian countries belong to those with the highest excretions. In a systematic review, high salt intake increased the GC risk by $68 \%$, and the association was stronger for Japanese and selected salt-rich traditional foods [110].

Short-term ingestion of traditional Japanese salty or vinegary food reproducibly caused reversible gastropathy with a higher mitotic activity in healthy men [111]. In Hawaiian Japanese men, nitrate-rich salty foods were related to gastric intestinal metaplasia [112], and high intake of salted cuttlefish and cod roe increased the agecorrected risk of CAG in Japanese women [113]. In a study of Japanese males from five regions with different GC mortality, CAG was not related to $H p$ but to salt excretion [114].

Salt and $H p$ interact in many ways [107]. High intake was related to higher $H p$ infection rates [106], and a permissive role of salt in $\mathrm{Hp}$ gastritis was proposed [109]. Reports about meat products are conflicting. The European EPIC trial found a positive association with GC [115], and British vegetarians had a $63 \%$ lower GC risk than meat eaters [116]. Conversely, low intake of meat and fish increased the risk in Venezuela [108]. High intake of salt and nitrate with food and seasonings in the East contributes to the EWD of CAG/GC, both synergistically and independent of $\mathrm{Hp}$.

\section{Fruits, Vegetables and Vitamins}

Fruits and vegetables confer protective effects against cancers, including GC, but results are inconsistent and may differ due to the type of GC (intestinal vs. diffuse) [117-119]. Studying overall consumption may yield negative results due to components with opposite effects. Yellow vegetables and high plasma $\beta$-carotene were associated with a lower risk of CAG among male Japanese [114]. Similarly, high intake of light-colored vegetables reduced CAG by $32 \%$ independent of $H p$ and age [52]. In Venezuela, high fruit consumption reduced CAG by $40 \%$, dysplasia by $60 \%$, and intestinal metaplasia by $15 \%$. 
In contrast, starchy vegetables increased the risk probably due to preparation and contamination [32].

The effects partially depend on vitamin C [120]. Ascorbic acid, the reduced form of vitamin $\mathrm{C}$, is secreted by the normal gastric mucosa depending on plasma levels maintained by dietary intake [121]. Poor vitamin C supply in cold areas may account for higher GC rates in northern versus southern areas [122].

Vitamin C levels were reported to be low in $\mathrm{Hp}$ gastritis and ulcer patients, but increased after $\mathrm{Hp}$ eradication $[94,120,121,123]$. Ascorbic acid reduced $H p$ acquisition $[124,125], H p$-induced inflammation and oxidative damage [121], prevalence of GC precursor lesions [117] and formation of carcinogenic $\mathrm{N}$-nitroso compounds in gastric juice. In Colombian high-risk patients, ascorbic acid and $\beta$-carotene induced histological regression of gastric atrophy and intestinal metaplasia [126]. Intake of total dietary fiber $[127,128]$ or cereal fiber [119] was related to a lower GC risk. Most East Asians prefer cooked or preserved vegetables to raw vegetables. This may add to increased susceptibility to CAG and GC in Asia.

\section{Dairy Products, Iron and Rice versus Wheat and Soy}

Reports about dairy products and milk are inconsistent. Studies from Louisiana and Venezuela reported an increased risk of CAG [117] or intestinal metaplasia [32] with high intake, others a risk reduction. In a meta-analysis, high intake of dairy products but not milk was protective in Western but not Asian studies [129]. The associations between iron deficiency and GC are confounded by blood loss and low absorption. Still, reports indicate an increased GC risk related also to low iron intake [127].

Higher DU rates in southern versus northern areas related to daily intake of rice, inversely related to wheat flour and independent of $H p$ infection, were reported in China and India $[122,130]$. In contrast, rice in Japan was associated with a higher risk of CAG [113] probably due to co-ingested salty food.

Reports about soybean products vary: high intake was related to an increased risk of CAG in a Japanese study [114] but was inversely related to GC death in others [131]. In Korea, a protective effect in females but not males was found [132], and in postmenopausal Chinese women, soy intake was inversely related to plasma levels of IL-6, TNF $\alpha$ and soluble TNF receptors [133].

The effect may differ according to salt content [107], fermented versus nonfermented products, conditions of fermentation, microorganisms [134] and toxigenic contaminants [135]. This may explain discordant results in different regions and in genders [131, 132, 136]. Soy products are used on a daily basis in East Asia. A beneficial effect on CAG/GC could be confounded by co-ingested irritants and could be gender dependent. Dairy products may be protective in the West.

\section{Smoking, Air Pollution, Alcohol, Tea and Coffee}

UK smokers had a higher prevalence of gastritis: 21 and $19 \%$ in nonsmokers or pipe and former smokers, $28 \%$ with 10-19 cigarettes, and $43 \%$ with $20+$ cigarettes per day [95]. Smoking is a risk factor of GC [137] and precursor lesions including CAG [78, 105, 112, 117]. Transition to dysplasia was higher in blood group A [78]. In a meta-analysis of 40 studies, the relative risk of GC was higher in men than women (1.6 vs. 1.1 ), and $11 \%$ of GC worldwide were attributed to tobacco smoking [138]. Almost identical numbers were reported in a more recent meta-analysis [139] and in the European EPIC trial [137]. Significant effects started from 10 cigarettes per day, depended on dose and duration and declined after stopping $[32,137]$. The risks of smoking and $\mathrm{Hp}$ for GC [140] and peptic ulcer [141] were additive, and smoking was an independent risk factor for GC in Fujian patients [142].

The higher risk of CAG/GC could be caused by swallowed constituents [95], inhaled toxins and other factors: increased bile reflux [143, 144], increased proinflammatory chemokines [145] and impaired mucosal defense (including low vitamin C [94]) in smokers. In a study from northeastern Japan, $44 \%$ of male participants of a health check program smoked versus $2 \%$ females [113], or 45 versus 3\% in Venezuela [108]. The predominance of precancerous lesions and GC among males may be related to smoking. Few reports related air pollution to GC [146]. Again, swallowed chemicals could be involved.

Alcohol was associated with CAG and GC in some [32, 147] but not all reports [52]. Of UK nondrinkers, $21 \%$ had gastritis versus $35 \%$ of heavy irregular drinkers, $46 \%$ of regular drinkers, and $63 \%$ of both heavy drinkers and smokers [95]. Green tea, but not black or Oolong tea, was associated with a $37 \%$ reduced risk of CAG after adjustment for $H p$ and other variables in Japan [148]. No relationship was found for coffee, alcohol or smoking. In males of the Japan Self-Defense Forces, green tea was related to a lower risk of CAG. [149]. High intake of hot tea was associated with a higher prevalence of gastritis in the UK population $[95,150]$. Smoking and air pollution in concert with alcohol and hot beverages may contribute to the risk of CAG/GC. A stronger inhibition of acid secretion in $\mathrm{Hp}$-infected Japanese males than females [25] may be an additional factor. 


\section{Conclusion}

Differences in CAG and associated diseases observed today reflect differences in $H p$ prevalence, virulence, host and environmental factors in the past. Because of fundamental changes in life conditions, correct evaluation requires a time frame of two centuries. Many secrets, therefore, will remain buried in the past. Still, the pathogenesis of gastritis in the East and West can be assumed to be fairly similar under similar conditions. Equally high GC and presumably CAG rates in Western countries occurred in the past when risk factors were comparable to those in the East. Due to the asynchronous elimination of CAG risk factors from the environment, striking geographic heterogeneity has evolved which will decline with further adoption of westernized lifestyles.

Some differences will continue to modify gastric disease outcomes. In many areas, $H p$ will soon cease to be one of them. What remains are inherited ethnic differences, among which lower parietal cell mass in Asians may be important besides cultural differences in lifestyle that hopefully will also be maintained in the future.

\section{Facts from East and West}

Although few East-West comparative studies have been done, the available data suggest that patients from East Asian countries show more severe endoscopic and histological manifestations of CAG compared to those from Europe or North America.

In both Asian and Western countries, the prevalence of $H p$ infection is linked to the incidence of GC. Asian countries, however, exhibit a higher incidence of GC.

Analysis of the $H p$ virulence genes points towards a central role of the CagA and VacA virulence factors. The
$H p$ strains may be classified into three types: East Asian CagA positive (EPIYA motif ABD type), Western CagA positive (EPIYA motif $A B C$ type), and CagA negative. In particular, the East Asian ABD type CagA strain is associated with higher pathogenicity. The presence of the $s 1$ and/or $\mathrm{m} 2$ VacA genotypes is associated with a greater risk of GC and peptic ulcers.

The individual's genetic background, including polymorphisms in several interleukin genes, TNFa, NOD1 and NOD2, may affect disease risk. Other host factors that influence disease risk are parietal cell mass and the $\mathrm{ABH}$-secretor and/or Lewis histo-blood group status. Some Asian populations express point mutations in the sej allele, which may facilitate bacterial attachment to the gastric mucosa. Asians have been shown to have smaller parietal cell masses than Western populations, affecting gastric acid secretion and response to treatment with proton pump inhibitors and histamine- 2 receptor antagonists.

Data on the protective effect of specific dietary elements remain conflicting. Soy products are widely used in Asia, but data on their beneficial effects depend on their salt content, fermentation and the presence of contaminants. Some Western studies have indicated that ingestion of dairy products may have protective effects on CAG and GC. Consumption of green tea has also been associated with a reduced risk of CAG in Japanese populations.

Environmental factors (such as air pollution) could act in concert with lifestyle factors (such as smoking and diet) to modulate an individual's risk of GAC or GC.

\section{Disclosure Statement}

The authors have no conflicts of interest to declare.

\section{References}

1 Siurala M, Varis K, Wiljasalo M: Studies of patients with atrophic gastritis: a $10-$ to $15-$ year follow-up. Scand J Gastroenterol 1966; 1: $40-48$.

- Walker IR, Strickland RG, Ungar B, et al: Simple atrophic gastritis and gastric carcinoma. Gut 1971;12:906-911.

- 3 Correa P, Haenszel W, Cuello C, et al: A model of gastric cancer epidemiology. Lancet 1975; 2:58-60.

Gastritis in East and West
4 Sipponen P, Kimura K: Intestinal metaplasia, atrophic gastritis and stomach cancer: trends over time. Eur J Gastroenterol Hepatol 1994; 6(suppl 1):79-83.

5 Sipponen P, Marshall BJ: Gastritis and gastric cancer. Western countries. Gastroenterol Clin North Am 2000;29:579-592.

6 6 Dixon MF, Genta RM, Yardley JH, Correa P: Classification and grading of gastritis. The updated Sydney system. Am J Surg Pathol 1996;20:1161-1181.
Rugge M, Fassan M, Pizzi M, et al: Autoimmune gastritis: histology phenotype and OLGA staging. Aliment Pharmacol Ther 2012;35:1460-1466.

8 Jönsson KA, Ström M, Bodemar G, et al: Histologic changes in gastroduodenal mucosa after long-term medical treatment with cimetidine or parietal cell vagotomy in patients with juxtapyloric ulcer disease. Scand J Gastroenterol 1988;23:433-441. 
$\longrightarrow 9$ Kuipers EJ, Lundell L, Klinkenberg-Knol EC, $>25$ Iijima K, Ohara S, Koike T, et al: Gastric acid et al: Atrophic gastritis and Helicobacter pylori infection in patients with reflux gastritis treated with omeprazole or fundoplication. $\mathrm{N}$ Engl J Med 1996;334:1018-1022.

10 Sugano K, Tack J, Kuipers EJ, et al: Kyoto global consensus report on Helicobacter pylori gastritis. Gut 2015;64:1353-1367.

11 Hunt RH, Camilleri M, Crowe SE, et al: The 27 stomach in health and disease. Gut 2015;64: 1650-1668.

12 Rugge M, Fassan M, Pizzi M, et al: Operative link for gastritis assessment vs operative link of intestinal metaplasia assessment. World J Gastroenterol 2011;17:4596-4601.

13 Stickland RG, Mackay IR: A reappraisal of the nature and significance of chronic atrophic gastritis. Dig Dis 1973;18:426-440.

14 Wyatt JI, Dixon MF: Chronic gastritis - a pathogenetic approach. J Pathol 1988;154: 113-124.

15 Kohli Y, Pfeiffer CJ, Kutty KP et al: Endoscopic diagnosis of intestinal metaplasia in Canada and Japan. J Clin Gastroenterol 1981;3(suppl 1):29-33.

16 Schlemper RJ, van der Werf SD, Vandenbroucke JP, et al: Seroepidemiology of gastritis in Japanese and Dutch working populations: evidence for the development of atrophic gastritis that is not related to Helicobacter pylori. Gut 1995;37:199-204.

17 Chen XY, van der Hulst RW, Shi Y, et al: Comparison of precancerous conditions: atrophy and intestinal metaplasia in Helicobacter pylori gastritis among Chinese and Dutch patients. J Clin Pathol 2001;54:367370.

18 El-Zimaity HM, Gutierrez O, Kim JG, et al: Geographic differences in the distribution of intestinal metaplasia in duodenal ulcer patients. Am J Gastroenterol 2001;96:666-672.

19 Kimura K, Sipponen P, Unge P, et al: Comparison of gastric histology among Swedish and Japanese patients with peptic ulcer and Helicobacter pylori infection. Scand J Gastroenterol 2003;38:491-497.

20 Lee I, Lee H, Kim M, et al: Ethnic difference of Helicobacter pylori gastritis: Korean and Japanese gastritis is characterized by maleand antrum-predominant acute foveolitis in comparison with American gastritis. World J Gastroenterol 2005;11:94-98.

21 Naylor GM, Gotoda T, Dixon M, et al: Why does Japan have a high incidence of gastric cancer? Comparison of gastritis between UK and Japanese patients. Gut 2006;55:1545-1552.

22 Siurala M, Sipponen P, Kekki M: Chronic gastritis: dynamic and clinical aspects. Scand J Gastroenterol 1985;109:69-76.

23 Wang WH, Huang JQ, Zheng GF, et al: Nonsteroidal anti-inflammatory drug use and the risk of gastric cancer: a systematic review and meta-analysis. J Natl Cancer Inst 2003;95: 1784-1791.

24 Tan VP, Wong BC: Gastric cancer chemoprevention: the current evidence. Gastroenterol Clin North Am 2013;42:299-313. secretion of normal Japanese subjects in relation to Helicobacter pylori infection, aging, and gender. Scand J Gastroenterol 2004;39: 709-716.

6 Kimura K: Gastritis and gastric cancer. Asia. Gastroenterol Clin North Am 2000;29:609621.

Blaser MJ, Kobayashi K, Cover TL, et al: Helicobacter pylori infection in Japanese patients with adenocarcinoma of the stomach. Int J Cancer 1993;55:799-802.

28 Watanabe Y, Kurata JH, Mizuno S, et al: $\mathrm{He}$ licobacter pylori infection and gastric cancer: a nested case-control study in a rural area of Japan. Dig Dis Sci 1997;42:1383-1387.

29 Fukuda H, Saito D, Hayashi S, et al: Helicobacter pylori infection, serum pepsinogen levels and gastric cancer: a case-control study in

30 Fukao A, Komatsu S, Tsubono Y, et al: Helicobacter pylori infection and atrophic gastritis among Japanese blood donors: a cross-sectional study. Cancer Causes Control 1993;4: 307-312.

31 Ohata H, Kitauchi S, Yoshimura N, et al: Progression of chronic atrophic gastritis associated with Helicobacter pylori infection increases risk of gastric cancer. Int J Cancer 2004;109:138-143.

32 Kato I, Vivas J, Plummer M, et al: Environmental factors in Helicobacter pylori-related gastric precancerous lesions in Venezuela. Cancer Epidemiol Biomarkers Prev 2004;13: 468-476.

- 33 Da Costa DM, dos Santos Pereira E, Barem Rabenhorst SH: What exist beyond cagA and $v a c A$ ? Helicobacter pylori genes in gastric disease. World J Gastroenterol 2015;21:1056310572.

34 Fujimoto S, Olaniyi O, Arnqvist A: Helicobacter pylori BabA expression, gastric mucosal injury, and clinical outcome. Clin Gastro-

35 Graham DY: Helicobacter pylori infection in the pathogenesis of duodenal ulcer and gastric cancer: a model. Gastroenterology 1997; 113:1983-1991.

-36 Graham DY, Lu H, Yamaoka Y: African, Asian or Indian enigma, the East Asian Helicobacter pylori: facts and medical myths. J Dig Dis 2009;10:77-84.

37 Cover TL, Peek RM: Diet, microbial virulence, and Helicobacter pylori-induced gastric cancer. Gut Microbes 2013;4:482-493.

38 Graham DY: History of Helicobacter pylori, duodenal ulcer, gastric ulcer and gastric cancer. World J Gastroenterol 2014;20:51915204.

39 Ito Y, Azuma T, Ito S, et al: Analysis and typing of the vacA gene from cagA-positive strains of Helicobacter pylori isolated in Japan. J Clin Microbiol 1997;35:1710-1714.

40 Higashi H, Tsutsumi R, Muto S, et al: SHP-2 tyrosine phosphatase as an intracellular target of Helicobacter pylori CagA protein. Science 2002;295:683-686. Japan. Jpn J Cancer Res 1995;86:64-71. enterol Hepatol 2007;5:49-58.
41 Sahara S, Sugimoto M, Vilaichone RK, et al: Role of Helicobacter pylori cagA EPIYA motif and $v a c A$ genotypes for the development of gastrointestinal diseases in Southeast Asian countries: a meta-analysis. BMC Infect Dis 2012;12:223-236.

42 Acosta N, Quiroga A, Delgado P, et al: Helicobacter pylori CagA protein polymorphisms and their lack of association with pathogenesis. World J Gastroenterol 2010;16:39363943.

43 Matsuhisa T, Yamaoka Y, Uchida T, et al: Gastric mucosa in Mongolian and Japanese patients with gastric cancer and Helicobacter pylori infection. World J Gastroenterol 2015; 21:8408-8417.

44 El-Omar EM, Carrinton M, Chow WH, et al: Interleukin-1 polymorphisms associated with increased risk of gastric cancer. Nature 2000; 404:398-402.

45 Furuta T, El-Omar EM, Xiao F, et al: Interleukin $1 \beta$ polymorphisms increase risk of hypochlorhydria and atrophic gastritis and reduce risk of duodenal ulcer recurrence in Japan. Gastroenterology 2002;123:92-105.

46 Shin WG, Jang JS, Kim HS, et al: Polymorphisms of interleukin-1 and interleukin-2 genes in patients with gastric cancer in Korea. J Gastroenterol Hepatol 2008;23:1567-1573.

47 Kamangar F, Cheng C, Abnet CC, et al: Interleukin-1B polymorphisms and gastric cancer risk - a meta-analysis. Cancer Epidemiol Biomarkers Prev 2006;15:1920-1928.

48 Sonnenberg A: Dietary salt and gastric ulcer. Gut 1986;27:1138-1142.

49 Haruma K: Trend toward a reduced prevalence of Helicobacter pylori infection, chronic gastritis, and gastric cancer in Japan. Gastroenterol Clin North Am 2000;29:623-631.

50 Kamada T, Haruma K, Ito M, et al: Time trends in Helicobacter pylori infection and atrophic gastritis over 40 years in Japan. Helicobacter 2015;20:192-198.

51 Correa P: The epidemiology and pathogenesis of chronic gastritis: three etiologic entities. Front Gastrointest Res 1980;6:98-108.

52 Shibata K, Moriyama M, Fukushima T, et al: Relation of Helicobacter pylori infection and lifestyle to the risk of chronic atrophic gastritis: a cross-sectional study in Japan. J Epidemiol 2002;12:105-111.

53 Kimura K, Takemoto T: An endoscopic recognition of the atrophic border and its significance in chronic gastritis. Endoscopy 1969;3: 87-97.

54 Kimura K: Chronological transition of the fundic-pyloric border determined by stepwise biopsy of the lesser and greater curvature of the stomach. Gastroenterology 1972;63:584-592.

55 Correa P, Schmidt BA: The relationship between gastric cancer frequency and the ratio of gastric to duodenal ulcer. Aliment Pharmacol Ther 1995;9(suppl 2):13-19.

56 Colquhoun A, Arnold M, Ferlay J, et al: Global pattern of cardia and non-cardia gastric cancer incidence in 2012. Gut 2015;64:18811888. 
57 You WC, Blot WJ, Li JY, et al: Precancerous gastric lesions in a population at high risk of stomach cancer. Cancer Res 1993;53:13171321.

58 De Martel C, Forman D, Plummer M: Gastric cancer. Epidemiology and risk factors. Gastroenterol Clin North Am 2013;42:219-240.

59 Park YH, Kim N: Review of atrophic gastritis and intestinal metaplasia as a premalignant lesion of gastric cancer. J Cancer Prev 2015; 20:25-40.

60 Cardenas-Mondragon MG, Torres J, FloresLuna L, et al: Epstein-Barr virus association with peptic ulcer disease. Anal Cell Pathol (Amst) 2015;2015:164840.

-61 Murphy G, Pfeiffer R, Camargo MC, et al: Meta-analysis shows that prevalence of Epstein-Barr virus-positive gastric cancer differs based on sex and anatomic location. Gastroenterology 2009;137:824-833.

62 Salazar CR, Sun J, Li Y, et al: Association between selected oral pathogens and gastric precancerous lesions. PLoS One 2013;8:e51604.

-63 Bento-Miranda M, Figueiredo C: Helicobacter heilmannii sensu lato: an overview of the infection in humans. World J Gastroenterol 2014;21:17779-17787.

-64 Tan P, Yeoh KG: Genetics and molecular pathogenesis of gastric adenocarcinoma. Gastroenterology 2015;149:1153-1162.

-65 Sipponen P, Hyvarinen H, Siurala M: H. pylori corpus gastritis - relation to acid output. J Physiol Pharmacol 1996;47:151-159.

-66 Stadelmann O, Elster K, Stolte M, et al: the peptic gastric ulcer - histotopographic and functional investigations. Scand J Gastroenterol 1971;6:613-623.

-67 Lam SK, Hasan M, Sircus W, et al: Comparison of maximal acid output and gastrin response to meals in Chinese and Scottish normal and duodenal ulcer subjects. Gut 1980;21:324-328.

68 Cheng FC, Lam SK, Ong GB: Maximum acid output to graduated doses of pentagastrin and its relation to parietal cell mass in Chinese patients with duodenal ulcer. Gut 1977;18:827832.

69 Card WI, Mark IN: The relationship between the acid output of the stomach following 'maximal' histamine stimulation and the parietal cell mass. Clin Sci 1960;19:147-163.

770 Leong RW: Differences in peptic ulcer between the East and the West. Gastroenterol Clin North Am 2009;38:363-379.

71 Iijima K, Shimosegawa T: Geographic differences in low-dose aspirin-associated gastroduodenal mucosal injury. World J Gastroenterol 2015;21:7709-7717.

72 Blackwell CC: The role of AB0 blood groups and secretor status in host defences. FEMS Microbiol Immunol 1989;47:341-350.

$\$ 73$ Le Pendu J, Lemieux RU, Lambert F, et al: Distribution of $\mathrm{H}$ type 1 and $\mathrm{H}$ type 2 antigenic determinants in human sera and saliva. Am J Hum Genet 1982;24:402-415.

74 Oriol R, Le Pendu J, Mollicone R: Genetics of $\mathrm{AB} 0, \mathrm{H}$, Lewis, $\mathrm{X}$ and related antigens. Vox Sang 1986;51:161-171.
75 Henry S, Oriol R, Samuelsson BE: Lewis histo-blood group system and associated secretory phenotypes. Vox Sang 1995;69:166182.

76 Vesely KT, Kubickova Z, Dvorakova M, et al: Clinical data and characteristics differentiating types of peptic ulcer. Gut 1968;9:57-68.

77 Aird I, Bentall HH, Fraser R: A relationship between cancer of stomach and the AB0 blood groups. BMJ 1953;1:799-801.

78 Kneller RW, You WC, Chang YS, et al: Cigarette smoking and other risk factors for progression of precancerous stomach lesion. J Natl Cancer Inst 1992;84:1261-1266.

-79 Edgren G, Hjalgrim H, Rostgaard K, et al: Risk of gastric cancer and peptic ulcer in relation to AB0 blood type: a cohort study. Am J Epidemiol 2010;172:1280-1285.

-80 Sipponen P Aärynen M, Kääriäinen I, et al Chronic antral gastritis, Lewis $(\mathrm{a}+)$ phenotype, and male sex as factors in predicting coexisting duodenal ulcer. Scand J Gastroenterol 1989;24:581-588.

81 Aspinall GO, Monteiro MA, Pang $\mathrm{H}$, et al: O antigen chains in the lipopolysaccharide of $H$. pylori NCTC 11637. Carbohydr Lett 1994;1: 151-156.

82 Borén T, Falk P, Roth KA, et al: Attachment of Helicobacter pylori to human gastric epithelium mediated by blood group antigens. Science 1993;262:1892-1895.

83 Ilver D, Arnquist A, Oeren J, et al: Helicobacter pylori adhesin binding fucosylated histo-blood group antigens revealed by retagging. Science 1998;279:373-377.

84 Mahdavi J, Sonden B, Hurtig M, et al: Helicobacter pylori SabA adhesion in persistent infection and chronic inflammation. Science 2002;297:573-578.

85 Gerhard M, Lehn N, Neumayer N, et al: Clinical relevance of the Helicobacter pylori gene for blood-group antigen binding adhesin. Proc Natl Acad Sci USA 1999;96:1277812783.

86 Clyne M, Drumm B: Absence of effect of Lewis $A$ and Lewis B expression on adherence of Helicobacter pylori to human gastric cells. Gastroenterology 1997;113:72-80.

87 Chen MY, He CY, Meng X, et al: Association of Helicobacter pylori babA2 with peptic ulcer disease and gastric cancer. World J Gastroenterol 2013;14:4242-4251.

88 Kudo T, Iwasaki H, Nishihara S, et al: Molecular genetic analysis of the human Lewis histo-blood group system. J Biol Chem 1996; 271:9830-9837.

89 Ikehara Y, Nishihara S, Yasutomi H, et al: Polymorphisms of two fucosyltransferase genes (Lewis and secretor genes) involving type I Lewis antigens are associated with the presence of anti-Helicobacter pylori IgG antibody. Cancer Epidemiol Biomarkers Prev 2001;10:971-977.

90 Yamaoka Y, Ojo O, Fujimoto S, et al: Helicobacter pylori outer membrane proteins and gastroduodenal disease. Gut 2006;55:775781.
-91 Sheu BS, Odenbreit S, Hung KH, et al: Interaction between host gastric Sialyl-Lewis X and $H$. pylori SabA enhances $H$. pylori density in patients lacking gastric Lewis B antigen. Am J Gastroenterol 2006;101:36-44.

92 Yamaoka Y: Increasing evidence of the role of Helicobacter pylori SabA in the pathogenesis of gastroduodenal disease. J Infect Dev Ctries 2008;2:174-181.

-93 Salama NR, Hartung M, Müller A: Life in the human stomach: persistence strategies of the bacterial pathogen Helicobacter pylori. Nat Rev Micobiol 2013;11:385-399.

94 Ruiz B, Rood JC, Fontham ET, et al: Vitamin $\mathrm{C}$ concentration in gastric juice before and after anti-Helicobacter pylori treatment. Am J Gastroenterol 1994;89:533-539.

-95 Edwards FC, Coghill NF: Aetiological factors in chronic atrophic gastritis. BMJ 1966; 2:1409-1415.

-96 Jainan W, Vilaichone RK: Effects of the CYP2C19 genetic polymorphism on gastritis, peptic ulcer disease, peptic ulcer bleeding and gastric cancer. Asian Pac J Prev 2014;15: 10957-10960.

97 Hofner P, Gyulai Z, Kiss ZF, et al: Genetic polymorphisms of NOD1 and IL-8, but not polymorphisms of TLR4 genes, are associated with Helicobacter pylori-induced duodenal ulcer and gastritis. Helicobacter 2007; 12:124-131.

98 Pan KF, Zhang L, Gerhard M, et al: A large randomised controlled intervention trial to prevent gastric cancer by eradication of $\mathrm{He}$ licobacter pylori in Linqu county, China: baseline results and factors affecting the eradication. Gut 2016;65:9-18.

-99 Wright ME, Andreotti G, Lissowska J, et al: Genetic variation in sodium-dependent ascorbic acid transporters and risk of gastric cancer in Poland. Eur J Cancer 2009; 45 : 1824-1830.

100 Duell EJ, Lujan-Barroso L, Llivian C, et al: Vitamin C transporter gene (SCL23A1 and SCL23A2) polymorphisms, plasma vitamin $\mathrm{C}$ levels, and gastric cancer risk in the EPIC cohort. Genes Nutr 2013;8:549-560.

101 Santolaria S, Barrios Y, Benito R, et al: Helicobacter pylori and immunogenic factors of the host: relevance of the HLADQA1 *0102 and ${ }^{*} 0301$ alleles in peptic ulcer. Gastroenterol Hepatol 2001;24:117-121.

102 Mayerle J, den Hoed CM, Schurmann C, et al: Identification of genetic loci associated with Helicobacter pylori serologic status. JAMA 2013;309:1912-1920.

103 Palli D, Decarli A, Cipriani F, et al: Plasma pepsinogens, nutrients, and diet in areas of Italy at varying gastric cancer risk. Cancer Epidemiol Biomarker Prev 1991;1:45-50.

104 Ikeda F, Doi Y, Yonemoto K, et al: Hyperglycemia increases risk of gastric cancer posed by Helicobacter pylori infection: a population-based cohort study. Gastroenterology 2009;136:1234-1241. 
105 Stemmermann G, Haenszel W, Locke F: Epidemiologic pathology of gastric ulcer and gastric carcinoma among Japanese in Hawaii. J Natl Cancer Inst 1977;58:13-20.

106 Tsugane S: Salt, salted food intake, and risk of gastric cancer: epidemiologic evidence. Cancer Sci 2005;96:1-6.

107 Wang XQ, Terry PD, Yan H: Review of salt consumption and stomach cancer risk: epidemiological and biological evidence. World J Gastroenterol 2009;15:2204-2213.

108 Munoz N, Plummer M, Viva J, et al: A casecontrol study of gastric cancer in Venezuela. Int J Cancer 2001;93:417-423.

109 Joossens JV, Hill MJ, Elliott P, et al: Dietary salt, nitrate and stomach cancer mortality in 24 countries. Int J Epidemiol 1996;25:494504.

110 D'Elia L, Rossi G, Ippolito R, et al: Habitual salt intake and risk of gastric cancer: a metaanalysis of prospective studies. Clin Nutr 2012;31:489-498.

111 MacDonald WC, Anderson FH, Hashimoto S: Histological effect of certain pickles on the human gastric mucosa. A preliminary report. Can Med Assoc 1967;96:1521-1525.

-112 Stemmermann GN, Nomura AM, Chyou $\mathrm{PH}$, et al: Impact of diet and smoking on risk of developing intestinal metaplasia of the stomach. Dig Dis Sci 1990;35:433-438.

-113 Montani A, Sasazuki S, Inoue M, at al: Food/ nutrient intake and risk of atrophic gastritis among the Helicobacter pylori-infected population of northeastern Japan. Cancer Sci 2003;94:372-377.

114 Tsugane S, Kabuto M, Imai H, et al: Helicobacter pylori, dietary factors, and atrophic gastritis in five Japanese populations with different cancer mortality. Cancer Causes Control 1993;4:297-305.

115 Gonzales CA, Jakszyn P, Pera G, et al: Meat intake and risk of stomach and esophageal adenocarcinoma within the European prospective investigation into cancer and nutrition (EPIC). J Nat Cancer Inst 2006;98:345354.

116 Key TJ, Appleby PN, Crowe FL, et al: Cancer in British vegetarians: updated analyses of 4998 incident cancers in a cohort of 32,491 meat eaters, 8612 fish eaters, 18,298 vegetarians, and 2246 vegans. Am J Clin Nutr 2014; 100(suppl):378S-385S.

117 Fontham ET, Zavala D, Correa P, et al: Diet and chronic atrophic gastritis: a case-control study. J Natl Cancer Inst 1986;76;621-627.

118 Freedman ND, Subar AF, Hollenbeck AR, et al: Fruit and vegetable intake and gastric cancer in a large United States prospective cohort study. Cancer Causes Control 2008; 19:459-467.

119 Bradbury KE, Appleby PN, Key TJ: Fruit, vegetables, and fiber intake in relation to cancer risk: findings from the European Prospective Investigation into Cancer and Nutriton (EPIC). Am J Nutr 2014; 100(suppl):394S-398S.
120 Aditi A, Graham DY: Vitamin C, gastritis, and gastric disease: a historical review and update. Dig Dis Sci 2012;57:1-22.

121 Sobala GM, Schorah CJ, Shires S, et al: Effect eradication of Helicobacter pylori on gastric juice ascorbic acid concentrations. Gut 1993; 34:1038-1041.

122 Wong BC, Ching CK, Lam SK, et al: Differential north to south gastric cancer-duodenal ulcer gradient in China. J Gastroenterol Hepatol 1998;13:1050-1057.

123 Rokkas T, Papatheodorou G, Karameris A, et al: Helicobacter pylori infection and gastric juice vitamin C levels. Impact of eradication. Dig Dis Sci 1995;40:615-621.

124 Rood JC, Ruiz B, Fontham ET, et al: Helicobacter pylori-associated gastritis and the ascorbic acid concentrations in gastric juice. Nutr Cancer 1994;22:65-72.

125 Goodman KJ, Correa P, Tengana HJ, et al: Nutritional factors and Helicobacter pylori infection in Colombian children. J Pediatr Gastroenterol Nutr 1997;25:507-515.

126 Correa P, Fontham ET, Bravo JC, et al: Chemoprevention of gastric dysplasia: randomized trial of antioxidant supplements and anti-Helicobacter pylori therapy. J Natl Cancer Inst 2000;92:1881-1888.

127 Harrison LE, Zhang ZF, Karpeh MS, et al: The role of dietary factors in the intestinal and diffuse histologic subtypes of gastric adenocarcinoma: a case-control study in the U.S. Cancer 1997;80:1021-1028.

128 Zhang Z, Xu G, Ma M, et al: Dietary fiber intake reduces risk for gastric cancer: a meta-analysis. Gastroenterology 2013;145: 113-120.

129 Guo Y, Shan Z, Ren H, et al: Dairy consumption and gastric cancer risk: a meta-analysis of epidemiological studies. Nutr Cancer 2015;67:555-568.

130 Tovey FI, Hobsley M, Kaushik SP, et al: Duodenal gastric metaplasia and Helicobacter pylori infection in high and low duodenal ulcer-prevalent areas in India. J Gastroenterol Hepatol 2004;19:424-430.

131 Nagata C, Takatsuka N, Kawakami N, et al: A prospective cohort study of soy product intake and stomach cancer death. Br J Cancer 2002;87:31-36.

132 Ko KP, Park SK, Yang JJ, et al: Intake of soy products and other foods and gastric cancer risk: a prospective study. J Epidemiol 2013; 23:337-343

133 Wu SH, Shu XO, Chow WH, et al: Soy food intake and circulating levels of inflammatory markers in Chinese women. J Acad Nutr Diet 2012;112:996-1004.

134 Kamo S, Suzuki S, Sato T: The content of soyasaponin and soyasapogenol in soy foods and their estimated intake in the Japanese. Food Sci Nutr 2014;2:289-297.

135 Jorgensen TR: Identification and toxigenic potential of industrially important fungi, Aspergillus oryzae and Aspergillus sojae. J Food Prot 2007;70:2916-2934.
36 Kweon SS, Shu XO, Xiang Y, et al: Intake of specific non-fermented soy foods may be inversely associated with risk of distal gastric cancer in a Chinese population. J Nutr 2013. 143:1736-1742.

137 Gonzalez CA, Pera G, Agudo A, et al: Smoking and the risk of gastric cancer in the European prospective investigation into cancer and nutrition (EPIC). Int J Cancer 2003;107: 629-634.

138 Trédaniel J, Boffetta P, Buiatti E, et al: Tobacco smoking and gastric cancer: review and meta-analysis. Int J Cancer 1997;72: 565-573.

139 Lareidas-Lopes R, Pereira AK, Nogueira A, et al: Smoking and gastric cancer: systematic review and meta-analysis of cohort studies. Cancer Causes Control 2008;19:689-701.

140 Siman JH, Fosgren A, Berglund G, et al: Tobacco smoking increases the risk for gastric adenocarcinoma among Helicobacter pyloriinfected individuals. Scand J Gastroenterol 2001;36:208-213.

141 Rosenstock S, Jorgensen T, Bonnevie O, et al: Risk factors for peptic ulcer disease: a population based prospective cohort study comprising 2416 Danish adults. Gut 2003; 52:186-193

142 Wong BC, Lam SK, Wong WM, et al: Helicobacter pylori eradication to prevent gastric cancer in a high-risk region of China. JAMA 2004;291:187-194.

143 Müller-Lissner SA: Bile reflux is increased in cigarette smokers. Gastroenterology 1986; 90:1205-1209.

144 Nakamura M, Haruma K, Kamada T, et al: Cigarette smoking promotes atrophic gastritis in Helicobacter pylori-positive subjects. Dig Dis Sci 2002;47:675-681.

145 Shimoyama T, Everett SM, Fukuda S, et al: Influence of smoking and alcohol on gastric chemokine mRNA expression in patients with Helicobacter pylori infection. J Clin Pathol 2001;54:332-334.

146 Chiu HF, Tsa SS, Chen PS, et al: Traffic air pollution and risk of death from gastric cancer in Taiwan: petrol station density as an indicator of air pollution exposure. J Toxicol Environ Health 2011;74:1215-1224.

147 Tramacere I, Negri E, Pelucchi C, et al: A meta-analysis on alcohol drinking and gastric cancer risk. Ann Oncol 2012;23:23-28.

148 Shibata K, Moriyama M, Fukushima T, et al: Green tea consumption and chronic atrophic gastritis: a cross-sectional study in a green tea production village. J Epidemiol 2000;10:310-316.

149 Kuwahara Y, Kono S, Eguchi H, et al: Relationship between serologically diagnosed chronic atrophic gastritis, Helicobacter pylori, and environmental factors in Japanese men. Scand J Gastroenterol 2000;35:476481.

150 Edwards FC, Edwards JH: Tea drinking and gastritis. Lancet 1956;271:543-545. 